\title{
Configurações
}

Revista de sociologia

$9 \mid 2012$

Trabalho e género: vidas precárias, percursos e acção colectiva

\section{Vidas operárias. A reconstituição etnográfica de contextos históricos em processo de (profunda) erosão social}

Workers' lives. The ethnographic reconstitution of historical processes in (deep) social erosion

Vies d'ouvriers. La reconstruction ethnographique des contextes historiques dans un processus de (profonde) érosion sociale

João Valente Aguiar

\section{OpenEdition}

Journals

\section{Edição electrónica}

URL: http://journals.openedition.org/configuracoes/1114

DOI: 10.4000/configuracoes. 1114

ISSN: 2182-7419

\section{Editora}

Centro de Investigação em Ciências Sociais

\section{Edição impressa}

Data de publição: 30 Junho 2012

Paginação: 57-80

ISSN: 1646-5075

\section{Refêrencia eletrónica}

João Valente Aguiar, « Vidas operárias. A reconstituição etnográfica de contextos históricos em processo de (profunda) erosão social », Configurações [Online], 9 | 2012, posto online no dia 27 novembro 2013, consultado o 22 abril 2019. URL : http://journals.openedition.org/configuracoes/1114 ; DOI : 10.4000/configuracoes. 1114

Este documento foi criado de forma automática no dia 22 Abril 2019.

(c) CICS 


\title{
Vidas operárias. A reconstituição etnográfica de contextos históricos em processo de (profunda) erosão social
}

\author{
Workers' lives. The ethnographic reconstitution of historical processes in (deep) \\ social erosion \\ Vies d'ouvriers. La reconstruction ethnographique des contextes historiques \\ dans un processus de (profonde) érosion sociale
}

João Valente Aguiar

\section{Introdução}

1 O Alentejo tem sido uma das regiões portuguesas atravessadas por dinâmicas vincadamente mais irruptoras e vorazes nos últimos cinquenta anos. Lembremos apenas que, em finais dos anos 60, dados oficiais (Ministério da Agricultura 2001) apontavam para uma população rural constituída por mais de $80 \%$ de assalariados agrícolas sem posse de terra, ao mesmo tempo que uma camada de cerca de $2 \%$ de grandes proprietários concentrava mais de dois terços das explorações agrícolas (cultivadas ou não) nos distritos de Portalegre, Évora, Beja e margem esquerda do Ribatejo.

2 Até à instauração do regime democrático o panorama nos campos alentejanos detinha propriedades sociais e políticas muito características, apesar de naturais nuances e matizações. Em traços gerais, o tecido social alentejano era marcado precisamente pela mencionada polarização social entre assalariados agrícolas e grandes proprietários agrários. Em termos políticos, durante o Estado Novo, a região foi atravessada por movimentações operárias de forte contestação ao regime e correspondente repressão por parte das autoridades da época. Por conseguinte, afigurava -se ali um caldo de intensa conflitualidade social, laboral e política. A isto acrescentem-se elevados índices de 
concentração fundiária e uma situação de profunda vulnerabilidade e precariedade laboral e social do lado do operariado agrícola. Tais eram os principais traços estruturais (e estruturantes) da estrutura económica e social dos campos alentejanos nos inícios da década de 70.

No período imediatamente subsequente ao 25 de Abril de 1974, a região alentejana viveu um processo de ocupações de terras que ficou conhecido por Reforma Agrária. Com o estertor desse projecto de apropriação colectiva das terras pelos assalariados agrícolas, o panorama da região alterou -se do ponto de vista demográfico e socioeconómico. 0 relativo estancamento populacional almejado na segunda metade da década de 70 (INE 1981) sofreu uma forte decomposição por efeito do incremento migratório para fora da região e, simultaneamente, a população ligada à actividade agrícola foi decaindo, atingindo actualmente menos de $10 \%$ da população activa (INE 2008), mais ainda quando grande parte do pouco que resta do actual operariado agrícola em actividade muito pouco ou nada tem a ver com o tipo de produção agrícola que ocorria no período acima reportado.

Nesse sentido, interessou -nos compreender em que medida as Ciências Sociais poderão lidar com um objecto de estudo praticamente desaparecido ${ }^{1}$ (a supramencionada erosão demográfica, económica, social e política da grande maioria do operariado agrícola alentejano, mais ainda o grupo social que desencadeou movimentações reivindicativas durante o Estado Novo). De facto, dada a escassez ${ }^{2}$ de estudos em torno das subjectividades produzidas naquele específico contexto histórico e local recorremos ao método biográfico - inserido numpainel metodológico global alicerçado na etnografia como possível via para efectivar uma tentativa de reconstituição (Burawoy 1991) das vivências e representações do operariado agrícola da época. No fundo, trata -se do que Simon Charlesworth denominou de «fenomenologia da experiência da classe trabalhadora» ou de «sujeito objectificante: a experiência de classe» (Charlesworth2000: 63 - tradução nossa).

5 Em poucas palavras, neste artigo apresentam -se, de um modo sequencial, uma breve incursão pela pesquisa de terreno etnográfica e pelo método biográfico como percurso metodológico e como painel de técnicas possíveis para abordar comportamentos (seç̧ão I) e, particularmente, significações veiculadas por agentes sociais que experienciaram directamente o contexto agrário alentejano durante o Estado Novo. De seguida, apresentam -se três histórias de vida (interpoladas mas interligadas entre si) acerca de dois tópicos centrais: 1) a profusão de sentimentos de solidariedade colectiva (secção II.1) que extravasam o plano político e se condensam, desde logo, ao nível dos discursos, das sociabilidades e da estruturação das suas identidades ${ }^{3}$ individuais e colectivas; 2 ) o relato pessoal do que os sujeitos entrevistados consideraram acerca das condições de vida, da repressão (secção II.2) e, de outro lado, da resistência (secção II.3) desses mesmos agentes ao regime ditatorial.

\section{0 método biográfico na pesquisa de terreno etnográfica}

Como afirmou António Firmino da Costa num ensaio marcante para o estudo da pesquisa de terreno em Sociologia, «um processo de estudo de caso intensivo não se pode socorrer duma única técnica, mas duma pluralidade delas, accionadas alternada ou 
simultaneamente pelo investigador» (Costa 2001: 140), pelo que a descrição de várias técnicas utilizadas numa investigação é um elemento essencial para uma recolha abrangente e multifacetada de informação qualitativa do nosso objecto de estudo. De acordo com Alvesson e Sköldberg, a metodologia qualitativa, pela sua natureza própria, para assegurar objectividade tem de ser «reflexiva» no sentido de «interpretar a interpretação» (Alvesson e Sköldberg 2001: 6) sociológica.

7 Começando pela técnica da entrevista, avance -se com a noção de que esta foi municiada em dois contextos distintos. Em primeiro lugar, enquanto instrumento de perscrutação exploratória do objecto de estudo. Neste âmbito, vários dos inquiridos foram alvo de entrevistas exploratórias com o intuito de aquilatar da viabilidade posterior de se construírem histórias de vida, tendo-se também realizado uma série de outras entrevistas a informantes privilegiados, no caso especialistas musicais em canto alentejano. Em segundo lugar, recorremos à entrevista como instrumento privilegiado de recolha de informação, nomeadamente no respeitante à indagação das experiências vivenciadas ${ }^{4}$ por operários agrícolas alentejanos. Naturalmente, a composição etária dos operários entrevistados situou-se acima dos 60 anos de idade, na medida em que o abordar de questões pretéritas à instauração do regime democrático em Portugal implicou considerar agentes sociais com tais características: actividade profissional relacionada com o trabalho nos campos; participação em eventos de contestação política e/ou social ao anterior regime; residência numa aldeia ou vila alentejana. Na aplicação das entrevistas semi-directivas aos agentes sociais considerados relembramos as palavras de João Teixeira Lopes de que as questões abertas e semi-abertas do guião requerem sempre «um enquadramento menos cartesiano, de maneira a que, em situação de entrevista, as respostas reflictam as singularidades dos universos simbólicos dos entrevistados» (Lopes 2000: 195). Noutros termos, apostou-se na construção de um guião que servisse de referência temática aos entrevistados onde estes, durante a entrevista, pudessem discorrer sobre o assunto mencionado como e quanto tempo lhes aprouvesse. Tentou -se, dessa forma, recolher a voz dos agentes sociais sobre uma série de tópicos referentes a dimensões significativas da sua vida.

8 Na sequência lógica do que acabou de ser exposto relativamente às entrevistas semidirectivas, surgiu, ao longo da investigação, a possibilidade de se realizarem histórias de vida. $O$ volume de informação e a extensão de áreas consideradas pelos agentes sociais entrevistados colocaram como desafio ao processo de pesquisa encetado a possibilidade de se construírem registos biográficos de operários agrícolas alentejanos. Parafraseando José Machado Pais, «os percursos biográfi cos foram desvendados por referência aos contextos» (Pais 2000: 20) sociabilitários de classe. No fundo, defrontados com a actual (quase) inexistência de redes de sociabilidade, surgiu como minimamente relevante utilizar os percursos biográficos como um resgate (possível) das dinâmicas de interacção presentes no universo cultural operário alentejano existente até meados da década de 80. Assim, a construção de «episódios sócio-biográficos» repercutiu, através de «entrevistas narrativas» a montagem simultânea de uma «plataforma hermenêutica» (idem: 19), no fundo, de uma peça técnica de recolha mas também de interpretação do objecto de estudo.

9 Repare-se que, para Dubar e Demaziére, a utilização robusta dos registos biográficos fundamentam, em paralelo, uma "postura analítica» por parte do investigador - a vigilância epistemológica constante do processo de recolha dos dados empíricos - e uma «reconstrução dos sentidos» (Dubar e Demaziére2004: 33) dos agentes sociais. 
Consequentemente, a aposta metodológica na técnica das histórias de vida potencializa a reflexão teórica e metodológica constante das variáveis em jogo (variáveis analíticas e conceptuais mas também de controlo objectivo do registo de campo) no processo de investigação.

Adicionalmente, gostaríamos de chamar a atenção para a questão da "verdade" e validade das histórias de vida. Daniel Bertaux adianta que se as histórias de vida «não nos dizem toda a verdade e nada mais do que a verdade» (Bertaux 1995: 2). Essa visão aparentemente paradoxal das narrativas biográficas prende-se com o facto de que estas não são suficientes para avaliar a realidade factual de determinados processos sociais e históricos. Porém, os registos biográficos permitem resgatar a "verdade" conforme ela é prestada pela voz e pela reflexão dos próprios agentes sociais. "Verdade" subjectiva dos agentes mas que é parte intrínseca do próprio processo real e objectivo. "Verdade" subjectiva dos agentes que influencia e é passível de transformar o processo real. "Verdade" subjectiva dos agentes que pode ser avaliada pelo seu confronto com factos e dados objectivos do próprio processo histórico.

11 Assim, a narrativa biográfica é perfeitamente enquadrável em termos de uma «performance» (Riessman 2003: 337) do agente. Uma performance onde o indivíduo dá inteligibilidade cognitiva e coerência ao seu percurso biográfico. Por sua vez, este é sempre contemplado ao nível do que Machado Pais chama de «biografias modais de casos extremos» (Pais 2000: 18). Quer dizer, casos biográficos que, sem perderem a sua singularidade, ilustram características transversais, no nosso estudo, a uma camada social específica da classe trabalhadora: os operários agrícolas alentejanos.

Por conseguinte, o método biográfico assume um conjunto de potencialidades interpretativas que importa explorar. Dar voz, passar a palavra, escutar o outro, constituem denodadamente exercícios inerentes ao método biográfico. Como Ferraroti reconhece, «a via da subjectividade é a que possibilita reconstruir o alcance objectivo de uma consciência individual, de grupo ou de época» (Ferraroti 1993: 86). O recurso às histórias de vida recria, pela evocação da experiência contada e vivida dos agentes sociais, uma nova manta de representações sociais e simbólicas. De facto, o método biográfico leva os agentes sociais a realizarem uma reflexão própria sobre um conjunto de acontecimentos e fenómenos que vivenciaram. No fundo, «o que está em jogo no uso do método biográfico é a recuperação de memórias narradas do ponto de vista de quem as evoca» (Pais 2001: 107), o que parece dar a entender que as histórias de vida trazem para o texto analítico a tessitura da subjectividade dos indivíduos. Assim, a análise sociológica enriquece -se aqui por via da recolha, tratamento e interpretação teórica do discurso dos agentes. Fundamentalmente, não se trata de fazer do discurso dos agentes matéria científica acabada ou sequer potencialmente explicativa, a apenas necessitar de uma translação da linguagem do senso comum para o vocabulário científico. Na verdade, o retomar das palavras dos agentes cumpre, essencialmente, uma função de captação de camadas do tecido social dificilmente apreensíveis por outros métodos e técnicas. Basicamente, a enunciação das representações individuais e colectivas não cabe ao investigador per si, mas este deve ouvir, recolher e, finalmente, interpretar o universo simbólico, cognitivo e afectivo dos agentes sociais. Daí que se tenha procurado tomar em linha de conta a seguinte elucubração de José Machado Pais: «em jogo», no método biográfico, "está também a possibilidade de tornar visível o que nem sempre é empiricamente detectável, precisamente as dimensões invisíveis de um fenómeno» (idem). 
13 Neste trabalho objectivaram -se um conjunto de vozes, isto é, um conjunto de testemunhos orais onde uma baixa directividade das entrevistas se resumiu ao levantar de tópicos centrais para que os respectivos agentes sociais discorressem livremente sobre o assunto. Por conseguinte, mais do que retratar vidas humanas na sua globalidade, pretendeu -se que os agentes sociais entrevistados alavancassem domínios de experiência operária num conjunto definido de temas directamente conectados com a formação do operariado agrícola alentejano e com a sua base de sustentação: a cultura popular assente em valores de solidariedade e de união colectiva. Recolher o «sentimento do período histórico» (James 2004: 290) [itálicos nossos] contemplado foi o desígnio analítico aqui em mãos, em especial no que toca ao propósito de objectivar as representações sociais e políticas de três operários agrícolas na sua concreção, na sua expressividade mais crua. Em poucas palavras, transformar os relatos desses trabalhadores em testemunhos orais.

\subsection{0 testemunho oral e a reconstituição (parcial) de um objecto de estudo: sentimento de comunidade e de solidariedade entre os assalariados rurais}

14 Como base do nosso trabalho, definimos o papel da cultura operária na formação da consciência política e social dos trabalhadores agrícolas alentejanos na resistência ao regime ditatorial do Estado Novo. Relembrando este tópico, passamos então a palavra aos agentes entrevistados ${ }^{5}$ e como estes apreendem a importância do colectivo e da solidariedade patentes nas redes de sociabilidade operárias.

CJ, operário agrícola com 68 anos de idade e proveniente da aldeia do Couço, concelho de Coruche, considera que nos trabalhadores alentejanos e ribatejanos da margem sul havia uma

consciência da solidariedade muito grande. A importância da solidariedade via -se, por exemplo, na que manifestávamos com os trabalhadores presos pelo regime. Naquele tempo afirmar os valores da democracia e da liberdade no contexto do regime ditatorial de Salazar era um enorme acto de coragem que só podia ser tomado colectivamente (CJ).

16 CJ aborda esta questão em termos simples, evidenciando o que para si era um dado a ter em linha de conta no seio daquela classe social: para que os trabalhadores alentejanos pudessem afrontar um regime político que consideravam como obstáculo à concretização dos seus interesses mais vastos e das suas necessidades mais prementes, só a sua agregação grupal poderia funcionar como aríete contra o Estado Novo. Todavia, a unidade colectiva dos trabalhadores não bastava, segundo CJ. Era preciso acrescentar-lhe

três formas de consciência: do mundo e do país em que viviam; da transformação social (mundo em constante mudança); do seu papel nesse processo de transformação Isto tinha depois ligação com o próprio conceito que o trabalhador alentejano tinha de posse da terra. Havia até um ditado onde se dizia, "a terra? Para que a quero eu a ter? Quando entro em casa até sacudo os pés!” (risos) (CJ).

17 Este "limpar a terra dos pés" conota uma noção de desprendimento em relação à propriedade individual e de despojamento corporal relativamente ao que não lhe é inerente. Neste capítulo, o entrevistado assume uma condição de desapossamento dos meios de produção como um factor caracterizador do assalariado agrícola alentejano (e de parte do Ribatejo). A este facto acrescenta -se que o referido sentimento de comunidade se repercute, por vezes, num certo 
sentimento de desconfiança de quem vem de fora, às vezes quase uma autarcia comunitária (CJ). asserção de que naquela região do país, e naquele contexto histórico, vivenciavam -se dois universos culturais e ideológicos. Redimensionando as suas vivências quotidianas num campo cultural e de sociabilidade próprio, o operariado agrícola alentejano secretava produtos simbólicos seus (canto popular, leitura colectiva de jornais oposicionistas nas praças das aldeias, etc.), em boa medida autónomos de influências de outras classes sociais. Tomando o conceito de cultura num domínio mais vasto, percebe -se, por conseguinte, como as redes de interacção, agrupamento colectivo e de sociabilidade inter-individual dessas comunidades rurais operárias consubstanciavam -se como fortes indutores de disposições morais, políticas, estéticas e significacionais claramente distintas das encontradas no seu exterior. A assunção destas experiências de vida passava por um sentimento de

naturalidade com que tudo foi feito ali. Por exemplo, as reuniões faziam -se com um petisco e com um copo mesmo sabendo que corríamos o risco de surgir a Guarda [GNR, nota nossa]. Isto permitia disfarçar as reuniões mas também porque víamos a luta com alegria e não com desespero, pelo menos da parte dos trabalhadores mais conscientes (CJ).

Essa vivência em comunidade consumava toda uma rede de sociabilidades e uma plataforma de produção profusa de conteúdos culturais muito próprios que se reflectiam no viver colectivo e político dessa classe. E que classe era essa? A que classe pertenciam aqueles agentes? Explicitando, a que classe social assumiam/ consideravam aqueles agentes sociais pertencer? Para GA, operário de Montemor -o -Novo com 81 anos de idade,

isto aqui eram operários agrícolas. É proletariado agrícola, não são camponese como lá no Norte. E não é por uma mania, é por uma razão científi ca. $O$ operário agrícola não tem nada seu, não tem terra sua, só tem dois braços. Isto é um operário industrial ou agrícola para trabalhar. Ele não é camponês. Por isso, chamávamos operários agrícolas aos trabalhadores agrícolas. Já em 62 havia essa consciência sentida de que eram operários agrícolas. É um raciocínio, é uma consciência de classe como tem um operário, não é? Para ele o que interessa é o trabalho não é a terra. Na Reforma Agrária, não quisemos a terra para nada, ela era para trabalhar (GA).

Expressa -se aqui uma insistência por parte do entrevistado de que a terra não é uma propriedade ou uma posse a ser apropriada individualmente, mas um recurso a trabalhar colectivamente. Paralelamente, a noção arreigada, historicamente reproduzida e reapropriada, de que os trabalhadores agrícolas da região eram, na sua esmagadora maioria, assalariados não deriva de uma mera constatação estatística. De facto, como se observou na introdução deste trabalho, parece ser relativamente evidente o elevado peso numérico e populacional do operariado agrícola em todo o Alentejo durante o período do Estado Novo. Contudo, uma certeza estatística e demográfica não é idêntica à subjectividade com que os agentes sociais apreendem a sua vivência, localização e condição social. Assim, o desenvolvimento de uma linguagem de classe - ainda por cima, assumindo explicitamente a pertença a uma determinada classe social - cristaliza uma orientação simbólica e ideológica marcada e corporizada pelos operários da região. Notadamente, estamos perante operários que residiam, sociabilizavam, conviviam e trabalhavam em unidades territoriais relativamente endógenas, portanto, no geral imunizadas culturalmente (e politicamente) das influências e dinâmicas das classes dominantes e das instituições do poder fascista nos campos (a União Nacional, os Grémios 
ou as Casas do Povo). GA acrescenta ainda que essa vida comunitária dos operários agrícolas alentejanos não dispensava o canto colectivo.

Às vezes cantava -se, juntava -se muita gente. Aos domingos, dia que não se trabalhava, juntavam-se aos 20, 30 de braço dado a cantar as canções que tínhamos na época. Havia canções de amor, de raparigas e tal, depois ia para outra rua e cantava-se outra sobre a terra e juntava -se muita gente. Nas ceifas, homens e mulheres cantavam. (pausa). Aí cantava -se muito. A tirar cortiça assobiava-se. A esgalhar cantava-se, esgalhar é limpar o relevo. Nas mondas, que era antes da monda química, as mulheres e os homens cantavam ao desafio. A música animava o pessoal. Sem ânimo não havia luta possível (GA).

21 Esta extensão da vida cultural a toda uma série de actividades produtivas cunha o viver operário numa multitude de sentimentos e numa gama vasta de acontecimentos recreativos, sempre perpassados pela solidariedade e pela celebração simbólica da colectividade em que se encontra(va)m.

Olha. Havia muitos convívios. Se passasses numa rua de uma aldeia, mesmo aqui em Beja, ias ver muita malta toda junta a cantar e a dançar. $O$ pessoal lá do norte às vezes tem aquela ideia de que nós alentejanos divertimo -nos pouco. Mas não. Divertir não é bem a palavra certa mas que havia uma alegria na vida do dia-a-dia das pessoas havia. Essa alegria era motor da nossa fraternidade para as lutas. Também havia muita gente a ler em conjunto e sessões de leitura. Lembro -me de ver um operário culto do partido [PCP, nota nossa], que tinha a quarta classe, a ler o "Até Amanhã, Camaradas" do Álvaro [Cunhal, nota nossa] para alguns operários que não eram do partido. Esse homem sabia até partes de romances de cabeça e contava isso na rua. (risos) Era muito giro. Claro que quando sentíamos a GNR a aproximar das ruas o pessoal debandava e dispersava logo. Também tínhamos que ter cuidado com os bufos. Mas nas aldeias era difícil ser bufo porque toda a gente conhecia-se, toda a gente comunicava entre si sempre que aparecia alguém de fora. As brincadeiras eram muito engraçadas na altura. As crianças brincavam sem brinquedos a fazer de conta que tinham brinquedos. Ou então fazíamos uns brinquedos com bocados de arame que às vezes se catava nas ruas. Parecíamos os meninos dos Esteiros (risos). Depois os miúdos andavam a pedir, a correr pela cidade, eram moços ao abandono. Tinha coisas más. A gente sabia que tinha de ir trabalhar muito cedo, muitos logo aos 5 ou 6 anos. Muitos nem à escola iam e eram raros os que tinham mais do que a instrução primária. Mas eu tenho a ideia que, apesar da miséria, essa vida de garoto descalço ajudou -nos a ser solidários desde meninos. O que um apanhava de comida num campo levava aos outros. Mesmo na escola havia separação entre os meninos das várias classes. Levávamos quase uma vida de malteses mas onde não havia traição entre nós. A traição da confiança era das atitudes mais graves e mais condenáveis que alguém poderia fazer (HJ).

Assim fala HJ (76 anos) de Baleizão, concelho de Beja. HJ corrobora igualmente a tese da incomunicabilidade cultural e sociabilitária entre os operários agrícolas e os grandes senhores da terra. Oferece ainda um exemplo concreto da forma de como (não) se relacionavam.

Com os latifundiários? Quase não falávamos, quando se falava. Era gente de grande insensibilidade. Por exemplo, o Dom Diogo em Ferreira do Alentejo. Não deixava no final da ordenha ou da apanha os trabalhadores aproximar-se e alimentar-se do que quer que fosse que sobrasse. Era de um desprezo para com a fome de quem lhe produzia a riqueza... Era um sujeito horrível. Uma outra situação que não gostava nada era quando alguns trabalhadores vinham com um chapéu pedir ao café Luiz da Rocha esmola. Eram uma excepção, era gente medrosa. Ou então quando os trabalhadores saíam às arrecuas de falar com dom Diogo. Isso sim era degradante. Mas eu não os culpo. A malta era muito pobre, passava fome e era natural que 
achassem que o senhor deveria ser benemérito. Aquela gente odiava os trabalhadores. Viam -nos como animais ou sei lá o quê (HJ). HJ exalta a solidariedade colectiva manifestada pelo operariado agrícola no passado.

Era uma solidariedade, uma união como não se vê hoje. Dou-te um exemplo, trabalhadores que davam o conduto ou parte dele para o homem conseguir resistir no trabalho. Alguns andavam com uma pedra na bolsa para fazer de conta que não se passava fome. Sol a sol, fome, nem sei como aquela gente aguentava as ceifas. Ainda por cima trabalhava-se três a quatro meses por ano. O resto do ano era desemprego. Aqueles olhos cavados de fome metiam impressão. Se não fosse a união entre a malta não sei o que teria sido de nós. Eram outros tempos e era um outro regime mas era uma ajuda entre os trabalhadores que não há hoje. Era espontânea e que era comum a gente que nem era politizada (HJ).

0 sentimento de injustiça relativamente às condições de vida existentes durante o regime ditatorial ajudou a fermentar um sentido colectivo de pertença de classe. Assim, a mobilização colectiva, mesmo no contexto da ditadura, assumia foros de maior desenvoltura na sua concretização.

Nos jogos de futebol, incentivava -se a participação da malta politizada ou do partido no jogo em cada equipa. O objectivo era aproveitar aqueles laços de união e ir mobilizando os trabalhadores. No fundo, a malta quando se sentia injustiçada lutava mais facilmente ( $\mathrm{HJ})$.

A mobilização política e social que, em muitos casos, o Partido Comunista Português, durante a ditadura, induziu junto do operariado agrícola alentejano, demonstra que a movimentação de contingentes populacionais em torno de determinadas reivindicações não é um puro e linear resultado da acção de um agente político organicamente exterior àquela classe social. Na realidade, a transversalidade de disposições (e de predisposições) baseadas em sentimentos de solidariedade, de desprendimento em relação à propriedade privada da terra e no afrontamento antagónico (simbólico e ideológico) entre trabalhadores e grandes proprietários, evidenciam, no seu conjunto, que sem determinados factores de índole ideológico -cultural, a mobilização política não teria o alcance que os seus resultados, à primeira vista, poderiam fazer crer.

\subsection{0 testemunho oral e a reconstituição (parcial) de um objecto de estudo: condições de vida e repressão durante a ditadura}

Durante a vigência do Estado Novo, as condições de vida para os trabalhadores agrícolas pautaram -se pela escassez de bens, pela fome, pelo desemprego. Para fazer frente a esses constrangimentos os trabalhadores constituíram praças de jorna que, pelo que se pode depreender das palavras de GA, seriam quase como que uma espécie de uma modalidade de implementar uma forma (incompleta) de contratação colectiva.

As praças de jorna foram inventadas pelos trabalhadores há muito tempo. Eram largos das aldeias, porque antes nas aldeias o proletariado agrícola em cada freguesia concentrava -se em largos. Era nos largos que havia um ou dois cafés ou tabernas onde os trabalhadores se juntavam mais. Em vez de o feitor comprar individualmente cada trabalhador, a gente juntava os trabalhadores no largo. Alguns patrões mandavam contratar ali o pessoal. Os trabalhadores aproveitaram isso para dizer que fulano tal oferece tanto e o outro oferece outro tanto e aí começaram a criar -se comissões de unidade, que era um grupo de quatro ou cinco formado ali naquela altura, e a gente dizia "a gente só sai daqui por tanto". E depois fazíamos intriga "fulano tal oferece tanto por isso não vou por tão pouco" (risos). As 
praças surgiram nos anos 30 de forma mais espalhada por todo o lado e ganharam muita força reivindicativa a partir dos anos 40. Aquilo formou-se naturalmente, pois há muitas décadas não havia aqui partidos, mas foi o Partido Comunista que lhes deu força de organização, como uma espécie de trabalho sindical na altura dos anos 40 (GA).

Portanto, um certo retrato de senso comum que objectiva nas praças de jorna um cenário de venda humilhante dos corpos humanos dispostos a trabalhar, no entender dos entrevistados, obscurece uma outra faceta que os trabalhadores agrícolas na sua vida laboral quotidiana aproveitaram para o que consideravam seu benefício: a organização e a reivindicação colectiva. Sobre o regime ditatorial propriamente dito os assalariados agrícolas alentejanos definem-no de uma forma bastante explícita.

O regime era cruel. O fascismo era como o partido [Partido Comunista Português, nota nossa] definia a "ditadura terrorista dos monopólios e dos agrários". Quer dizer, a gente, isso não era um palavrão, era uma realidade. o fascismo é a ditadura do capital mais agressivo que esmaga todas as liberdades. Não há partidos, não há imprensa, não há informação, não há liberdade de organização, não há eleições. Os governantes não são eleitos, são escolhidos, né? O regime era quase a mesma coisa que a classe dominante. Os governantes quase todos eram filhos de grandes capitalistas, de grandes proprietários. Eles não eram governantes do povo, eram um comité executivo do grande capital. Depois o fascismo tinha um aparelho repressivo muito cruel. o pior de tudo era a polícia política que mandava em tudo. Ela era absoluta. Podia prender um ministro do Salazar, quem quisesse. Era uma polícia com poderes absolutos e muito cruel. E eu sei porque por lá passei. Eu fui provavelmente dos mais torturados. Eu aqui hoje vivo nem sei como... Quase que agradeço à Nossa Senhora (risos). É quase um milagre porque eu fui espancado durante 14 horas seguidas com pequenas pausas, até cair ao chão. Tive equimoses no corpo durante um ano! Depois de ser espancado! Na segunda prisão fui espancado 14 horas de uma forma bárbara. Entrei às sete da manhã e só saí às nove. Na terceira prisão, em 71, estive dezoito dias, dezoito dias e dezoito noites seguidas sem dormir! Podia ter um colapso! Naquela altura já não somos bem uma pessoa. Uma pessoa que me visse antes de ir para a tortura e me visse depois não me reconhecia. Estava quase desfi gurado. Parecia um velhinho todo enrugado com uma cor esquisita, de cadáver. Éramos como cadáveres, era a morte lenta. Nem há palavras para descrever a tortura do sono. Em muitos aspectos é muito pior do que a porrada, é pior porque aquilo vai lentamente, a gente leva pancada e é para ir para ela. A reacção que a gente tem é para se mexer, para se defender. A tortura do sono é lenta e a gente perde... A gente deixa de ouvir, começa a ter alucinações visuais, parece que depois estamos a ouvir um filho, uma companheira ou um irmão a falar ao nosso lado, começamos a ver o que não é verdade. Começamos a cair assim com grandes quedas que até assustam a gente. Quer dizer, começam a dar -se fenómenos, começamos a sentir fenómenos que a gente quase que deseja morrer. A gente tem é vontade que morra. É uma tortura de uma crueldade que não dá para explicar. Por isso o fascismo a usou, matou e fez prisões (GA).

GA começa por descrever o regime de Salazar e Marcelo Caetano a partir das coordenadas da sua aprendizagem política - a famosa e repetida fórmula do dirigente comunista Álvaro Cunhal da «ditadura terrorista do grande capital» (Cunhal 1974: 20). Isto independentemente de enveredarem sempre por uma glorificação quase religiosa e reverencial da sua pertença política. Ao mesmo tempo, invoca um elemento histórico relativamente consensual na historiografia como a ausência de liberdades políticas durante os 48 anos do regime. Esta consciência acerca do seu posicionamento político e ideológico relativamente ao regime político de então leva-o, seguidamente, à sua própria experiência pessoal de preso e torturado nos cadafalsos da polícia política. 0 discurso de GA é sociologicamente pertinente neste ponto, precisamente pela sua capacidade de ter 
discorrido de observações gerais sobre o regime e por ter as ter relacionado com a sua vida concreta. No fundo, ressalte -se o facto de os discursos destes agentes sociais contemplarem a noção de que as estruturas sociais, económicas e políticas não são meros enunciados etéreos, mas têm uma materialização real e concreta nas suas vidas ${ }^{6}$. Os agentes sociais incorporam - no caso, o corpo torturado - dinâmicas inerentes às estruturas. Esta consciência das marcas incorporadas e corpóreas no seu ser físico e psicológico (Wacquant 2004) caminhava lado-a-lado com o que consideravam ser a necessidade para as enfrentar e pôr cobro à sua existência. Quer dizer, a constituição de indivíduos pertencentes ao operariado agrícola alentejano num sujeito colectivo consubstancia, na realidade histórica da sua luta e contestação contra a ditadura, o efeito retroactivo de práticas sociais sobre as estruturas económicas e políticas que sustentavam o regime. Estas não seriam transformadas antes da Revolução de 1974, porém, a instauração do regime democrático não seria possível sem a erosão que práticas colectivas de contestação foram desencadeando. Segundo as palavras de um dos intervenientes, tais movimentações políticas e sociais durante o regime do Estado Novo sucediam -se da seguinte maneira.

No geral, as maiores lutas eram nos sítios com maiores concentrações de operários. Nos ranchos, os trabalhadores juntavam -se e nós com a nossa malta que era geralmente muito bem acolhida pela população organizávamos lutas. Muita gente via as praças de jorna apenas de um ponto de vista negativista, de humilhação dos trabalhadores perante o patrão. Havia mesmo quem defendesse a negociação individual do trabalhador com o patrão. Mas isso não era negociação, era pôr o trabalhador mais vulnerável perante quem é mais poderoso, o patrão ou o feitor. Por isso, a praça de jorna por juntar os trabalhadores todos ajudava muito à luta que é como quem diz a no final da manhã obtermos mais alguns escudos por jorna. O que naquele tempo não era de deitar fora! (HJ).

Mais uma vez a consideração das praças de jorna como um mecanismo de organização colectiva das reivindicações operárias e a assunção da luta reivindicativa em torno de melhores salários e melhores condições laborais como motor para a agregação colectiva dos trabalhadores alentejanos. Sobre as praças de jorna $\mathrm{HJ}$ acrescenta,

as praças de jorna são quase medievais e foi segundo alguns uma criação dos trabalhadores para se juntarem e imporem condições mais favoráveis de salário ao feitor. Ao feitor porque era este que escolhia os trabalhadores a contratar. Claro que os feitores tinham muito poder e colocavam os trabalhadores numa posição delicada. Eles quando já tinham alguma experiência não queriam os trabalhadores mais activos. Mas as praças de jorna eram, como dizia o Soeiro Pereira Gomes, uma forma central de organização dos trabalhadores. Lembro -me perfeitamente de uma luta que travamos pelos 50 escudos. Havia, como haverá sempre, trabalhadores mais tímidos e medrosos e o patrão aproveitava esses tentando virar o bico ao prego da nossa luta. Junto da grande maioria dos trabalhadores daqui havia um sentimento de revolta muito grande. Havia alguma humilhação quando nos sentíamos vendidos na praça de jorna mas a malta também não suportava aquilo, aquela miséria, aquela exploração. Portanto, a gente acabava por não se misturar com os agrários. Os feitores ainda eram piores. Como a gente costumava dizer, o feitor ainda era mais mau do que o patrão, tinha a mania que era mau e que mandava. Geralmente era filho de trabalhadores e mostrava-se ressentido com a sua origem, com as suas raízes. Daí que no plano pessoal se comportasse mais duramente connosco. Por outro lado, era ele quem tinha de nos contratar na praça de jorna. Logo tinha de se mostrar mais mau (HJ).

Por outro lado, HJ não se coíbe de enunciar a repressão e a violência física do regime contra os seus contestatários, inclusive o próprio. 
A repressão era impiedosa. A gente sofre mas também sabemos o nosso valor. Pois se o fascismo com a repressão toda não acabou com o partido não é agora que vão conseguir. o que eu quero dizer é que o fascismo é tenebroso mas quando defendemos ideais justos a malta sabe que mais tarde ou mais cedo, depois de levar muita porrada e de levar em cima muito sofrimento, vai derrotá -los. O problema no fascismo era a repressão e o medo, não propriamente a resignação.

Quanto à minha experiência pessoal, fui preso em 52. Sofro a tortura do sono. A tortura de sono é uma coisa terrível. Fala -se aí pelos jornais e televisões que o regime do Salazar não era fascista e não sei que mais. A verdade é que era. Os tipos daqui até eram mais inteligentes do que os seus amigalhaços alemães. Os nazis prendiam para matar mas não colhiam informações nenhumas de gente que dava com a língua nos dentes. Os mortos não falam, né? Mas a tortura do sono desmoraliza o preso, faz -lhe perder o tino e foi por isso que gente menos experimentada na luta e com menos fibra acabou por falar na PIDE. Acabei por estar uma semana na tortura do sono. No final só via alucinações. Era uma coisa horrível. Por isso, o regime era mesmo fascista. Contra os que hoje querem pintar de cor de rosa o regime. A gente sabe muito bem o que eles querem e o que são. $O$ regime protegia os latifundiários. O Salazar era uma marioneta daqueles. Os latifundiários estavam todos com o regime. Isso era claro que estava contra os interesses dos trabalhadores que eram pessoas como as outras e tinham direito a viver não eram animais. Para mim, ser -se antifascista é uma questão de dignidade» (HJ).

31 Tal como GA, HJ constrói a sua visão sobre a ditadura salazarista partindo de considerações gerais sobre a sua natureza política, desembocando na sua experiência pessoal enquanto preso político. No final, HJ sumaria a relação do regime com a classe social dominante nos campos, notando -se um esforço, sublinhe-se, pessoal de assinalar a ligação daquele regime político a determinadas práticas autoritárias sobre os indivíduos, terminando com a ênfase moral de resistência como uma "questão de dignidade". Portanto, a presença de valores de solidariedade e a constituição daquela classe social como um agente colectivo durante o Estado Novo encarreiraram em fortes e declarados sentimentos de auto -identifi cação. Uma auto-identificação que cruzava uma assumpção relativamente tácita da pertença de classe e uma ligação constante de determinados apontamentos políticos, ideológicos e sociais sobre o regime com a experiência pessoal dos protagonistas.

\subsection{0 testemunho oral e a reconstituição (parcial) de um objecto de estudo: lutas operárias no Estado Novo}

32 À vida de duras privações e de forte repressão existia uma outra face da moeda: a resistência. Resistência política que não se expressava num mero abraçar de ideais. Actos clandestinos de propaganda, reuniões a altas horas da noite ou a organização de manifestações reivindicativas ou políticas têm por debaixo de si um substrato de forte imbricação entre as «estruturas mentais» dos agentes sociais e as «estruturas objectivas» (Bourdieu 1998: 10) constitutivas de um determinado espaço social. Portanto, as disposições incorporadas pelos agentes sociais e os correlativos processos de construção da sua identidade articulavam essa ligação entre comportamentos e acções concretas de resistência política e dimensões estruturais do espaço social inscrito nas aldeias e nos campos alentejanos.

Essa auto-identificação operária aportava necessariamente um carácter normativo na exposição/exteriorização das disposições do habitus ${ }^{7}$ assalariado agrícola alentejano. Quer dizer, orientava a reflexão que os indivíduos tinham sobre o regime ditatorial em que 
viviam mas também os motivava a agir. Nesse sentido, essa «consciência de classe» (Lukacs 2003; Burawoy 1979; Wright 1997), o «quadro de interacção» (Costa 1999) que orienta e monitoriza a acção daqueles agentes sociais tem uma base cultural e uma base política. De um lado, essa consciência de classe não está desligada de valores, de representações mentais, de noções e de ideias sobre o mundo social. Portanto, tem como matéria-prima símbolos e valores. De outro lado, essa rede axiológica substantiva-se na arena política, isto é, plasma -se no real -social não apenas nas observações verbais e cognitivas sobre um determinado actor político e social, mas efectiva-se em acções concretas.

A 23 de Junho de 1958 lembro -me de uma greve política contra a fraude eleitoral. Também tivemos muitas lutas nas campanhas de Arlindo Vicente e de Humberto Delgado. Era jovem na altura quando fizemos o Encontro Nacional de Jovens na sequência das eleições de 1958. Na preparação deste tivemos uma reunião na aldeia do Couço com 150 jovens à noite. No ano seguinte, tivemos lutas reivindicativas e com uma componente cada vez mais política. Não houve lutas específicas da juventude mas lutas pela paz, etc. Nesse ano de 59, houve no Couço mais de 200 presos. Recordo -me de na altura se ter dito que «não prenderam mais porque não tinham carros que chegassem» (risos). o Couço sempre foi uma terra de grandes tradições de luta e, claro, de repressão sobre os trabalhadores. Acho que os primeiros presos no Couço foram em 1933 - foram levados a pé até Santarém (CJ).

A memória das lutas operárias conforme enunciadas pelos sujeitos é um dado a registar. Memória das lutas vividas mas também das lutas "sabidas", apre(e)ndidas e contadas e recontadas. A constituição de um veio histórico nos discursos operários era um elemento vital dessa consciência de classe.

A República foi implantada no Couço em Agosto de 1910. O Humberto Delgado ganhou no Couço porque houve capacidade de colocar trabalhadores a fazer a fiscalização dos cadernos eleitorais e das mesas eleitorais. Ganharam-se lá todas as eleições no tempo do fascismo (CJ).

O sentimento de orgulho (e de glorificação triunfalista da sua conduta política) em ligar a sua localidade a uma herança de luta, de contestação e reivindicação demonstra o quanto as dimensões de lugar e de comunidade (variáveis culturais fortemente presentes na cultura operária popular alentejana) se conectam com a disponibilidade para a mobilização colectiva (variável política) daquela classe social.

Por exemplo, em 1958, no tal dia 23 de Junho, os trabalhadores ocuparam a cidade. A PIDE prende três organizadores da greve, por sua vez a população prende a GNR no quartel e corta as linhas telefónicas, a aldeia fi ca no nosso controlo por três dias. Depois entraram as tropas. A malta também fez um primeiro esboço de Reforma Agrária, pensamos no que fazer com as terras e viu -se que era a posse colectiva das mesmas (CJ).

Prosseguindo na catalogação das lutas por que passou, CJ enumera a das

8 horas no Couço em 1962. A partir de 2 de Maio entramos às 8 horas, parávamos ao meio -dia para almoçar uma hora e depois saímos às 17 horas. Era ver os capatazes a berrar e nós a não ligar nenhum (risos) (CJ).

Por seu turno, GA descreve e relata um dos episódios mais conhecidos da luta operária alentejana contra o regime - o assassinato da ceifeira Catarina Eufémia - secundarizando, contudo, as lutas desse ano de 1954 às de 1962:

Em 1954 mataram a Catarina mas não foi dos anos... Não foi um ano significativo como 62. Agora em 54 o que marcou aqui mais foi a greve nas ceifas, por melhores reivindicações. Foi por todo o Alentejo. O Baixo Alentejo teve esse confronto específico, Baleizão, eles foram para a grevee... O proprietário chamou a Guarda 
para pôr os trabalhadores a trabalhar. Aí dá-se um confronto. As mulheres avançam, cortam o cordão dos guardas, conseguiram passar e foram ter ao rancho onde andavam a trabalhar outras ceifeiras. Lá, estavam mais patrulhas da Guarda Republicana coordenada pelo Tenente e é aí que matam a Catarina. Os guardas ficaram espantados. Como é que elas aqui aparecem. Não esperavam que furassem o primeiro cordão. Dispararam. Um agente cruel, uma coisa muito cruel. E pronto estive nessas lutas de 54. Em 1962 é uma fase mais avançada da luta do nosso povo. Tinham irrompido a guerra colonial e agrava-se a crise do fascismo. Portanto, a expressão da luta já era mais avançada um pouco. (GA)

A consciência de que a dinâmica histórica e social, onde as movimentações populares da região se inserem, é dotada de processualidade expressa -se no enquadramento cronológico realizado às iniciativas de $1962 \mathrm{em}$ luta pelas oito horas de trabalho nos campos:

Antes disso quando o processo de luta começa a acelerar contra o fascismo, foi em 1958 com o processo eleitoral para presidente da república em que participa o Arlindo Vicente e o Humberto Delgado. E, portanto, isso acelera bastante a luta. E já vinha de trás, desde 57, a luta por um contrato de trabalho e pelas oito horas no campo. Este processo, a luta mais avançada, e mais demorada... Demorou anos a preparar! Porque sobre as oito horas no campo nunca se tinha falado (risos). Os grandes agrários e proprietários não podiam ouvir falar disso. Mesmo da parte dos trabalhadores diziam «mas como é que é isso das oito horas? Como isso é possível nas condições do campo?». Então o partido, que tinha uma grande organização, estava muito implantado nas principais localidades do Alentejo, com fortes organizações. E eu estava aqui. Entrei nessa altura como funcionário do Partido em 52. Em 62, só eu como funcionário do partido, fui a dezenas ou centenas de reuniões de trabalhadores. Reuniões de comissões de unidade, que no fundo eram comissões sindicais, né? E aí foi -se levantando o problema das oito horas. (GA)

Portanto, processos históricos mais amplos - no caso, a oposição de parte significativa do operariado agrícola alentejano ao regime do Estado Novo - enquadram séries múltiplas de actos microscópicos à luz dos olhares mais centrados na macro -história. Práticas aparentemente banais e sem um impacto directo no momento da sua execução compõem, afinal, uma sequência de laços e de elos moleculares onde vai fermentando a «formação da classe trabalhadora» (Thompson, 1991; Koo, 2001) alentejana.

Chegando a 62, tínhamos antes sofrido várias prisões. Eu tinha sido preso antes em 1960 em Beja. Eu fui preso e outros funcionários também foram presos e a luta antes de 62 foi um pouco abaixo. Nalguns sítios ficamos a dançar na corda bamba. Faltou a cabeça. Foram logo presos quatro funcionários, quatro funcionários e que estavam envolvidos na luta. Aí, nesse período, a luta que o partido desenvolveu, com muitas reuniões e plenários de trabalhadores... Eh pá, eu na clandestinidade, há gente que nem pensa que isso fosse possível, eu cheguei a ir a reuniões com mais de duzentas pessoas. De noite! Não houve um respeito pelas regras que a gente tinha para se proteger e a Guarda uma vez chegou a aparecer. Chegou a Guarda, não falamos de política, falamos de outras coisas. Pronto... Este trabalho feito desenvolveu -se ao longo dos anos e chegou -se a 1962 com as oito horas como reivindicação central. Porque foi só em 62? Porque antes não havia condições. Porque esta luta exigiu uma grande preparação, de organização e de esclarecimento (ênfase na voz), dizendo que era possível as oito horas e que o trabalho de sol a sol... Muita gente não sabe o que era isto, que era uma escravatura, era quase uma escravidão, pegar no trabalho ao nascer do sol e deixá-lo ao pôr, portanto, trabalhava -se doze horas ou mais de Verão e com este calor infernal... Portanto, as oito horas eram uma aspiração profundamente sentida pelo proletariado agrícola (GA).

40 A importância que GA dá às lutas de 1962 não significa, portanto, que este marco central da mobilização operária no Alentejo seja um episódio desligado de um processo que lhe 
está subjacente e lhe deu escopo e sustentação material. Ao mesmo tempo, existe uma racionalidade estratégica intrínseca à determinação da mobilização no mês de Maio de 1962.

Em 62 começamos a discutir qual a data, qual a melhor data. E por razões históricas... Bem, o Primeiro de Maio simboliza a luta dos trabalhadores. É o símbolo da luta pelas oito horas! Depois a crise do fascismo era muito maior. As três frentes na Guerra Colonial... O fascismo sente -se mais isolado. O Maio, nos anos 60, é aqui no Alentejo a data da pressão dos serviços agrícolas. É a ceifa, a cortiça, as debulhas, o arroz, quer dizer, muitas coisas a apertar. Apertar os patrões, forçar os patrões a ceder. E havia uma grande vontade dos trabalhadores em ir para a greve (esboça um sorriso). Sabia -se que era uma luta dura, muito dura porque era um desafio. Era um desafio ao fascismo e um desafio ao poder dos agrários. Aos senhores das terras. Nessa altura, o Primeiro de Maio foi um domingo e portanto o Partido fez um manifesto num A3, num A5 perdão. Em papel de seda. Milhares e milhares que se fizeram com um apelo dirigido aos trabalhadores. Foi uma grande luta. Na altura escrevemos 350 mil - que eram todos os que existiam - no Camponês mas foram mais de 200 mil. Em toda a zona ao sul do Tejo, daquela parte do Ribatejo ao sul do Tejo, todos os distritos do Alentejo mais o Litoral. Portanto, lançou -se esse documento, saí da cadeia em Dezembro de 61 e fiz o apelo. Não temos hoje esse apelo. Nem a direcção do partido tem. Desapareceu. 0 apelo também era simples: "no dia Primeiro de Maio nenhum trabalhador deve trabalhar mais do que as oito horas". Este era o sentido do apelo. E mais, "onde os capatazes e os proprietários não aceitarem as oito horas, devem os trabalhadores impô-las". E foi assim. Isto foi uma coisa aceite e com uma adesão enorme logo na segunda -feira. Começou no Litoral Alentejano e foi um cavalgar, um galgar de terra para terra, de freguesia para freguesia, de concelho para concelho, e em três meses as oito horas estavam implantadas em praticamente toda aquela enorme região. Ficaram alguns proprietários muito renitentes e teimosos porque não queriam dar as oito horas, não recolhendo as culturas, despedindo malta, mas no fim de 1962 as oito horas estavam em todo o lado (GA).

41 A sinceridade que GA procura imputar ao seu discurso passa por assumir o que considerou o verdadeiro número de grevistas - 200 mil numa população operária na época de cerca de 350 mil, ou seja, mais de metade do contingente laboral - e repercute se na informação dada acerca das disputas com que essa onda de greves e de lutas foi discutida nas direcções regionais e central do PCP. Mais uma vez se constata a exaltação deste partido político por parte dos protagonistas aqui entrevistados. De facto, não deixa de ser relevante observar como estes agentes sociais depositavam naquele partido parte da responsabilidade por acções políticas e sociais que os trabalhadores desencadearam por sua própria iniciativa e por sua intenção e que ultrapassava em muito a dimensão e a capacidade logística de um partido político com apenas dois a três milhares de militantes em todo o país (Lisi, 2007: 186). A este propósito visualize-se no seguinte excerto a forma como GA testemunha as dúvidas existentes no PCP relativamente às lutas de 1962.

$\mathrm{Na}$ direcção do partido havia camaradas meus que tinham muitas dúvidas se esta greve não era uma aventura. Podia trazer muita repressão, mortes, e portanto...

Encontrei muitos camaradas que não acreditavam que os agrários e o fascismo cedessem. Mas nisto, a luta era tão poderosa e forte que o fascismo teve que recuar. Logo a seguir a greve, os proprietários faziam reuniões na rua com os elementos do Instituto Nacional do Trabalho, com o governo civil, com a GNR "como vamos pôr termo a isto?". E não foram capazes (brilho nos olhos). Aqui não havia nada a fazer. Houve locais onde os patrões não queriam ceder e a malta foi para a greve e mais nada! E nas terras e nas aldeias - quase todas tinham Guarda Republicana - o pessoal juntava-se na praça, nos largos, nos cafés, juntava a malta e lá vinha a Guarda Republicana. E diziam eles “então porque não vão trabalhar?". E a malta 
respondia "nós queremos trabalhar, mas só as oito horas. Dêem-nos as oito horas e nós vamos já trabalhar". E os guardas calavam -se logo (GA).

42 A convicção dos agentes sociais no que consideravam a justeza das propostas reivindicativas avançadas, as pequenas lágrimas de felicidade com a vitória laboral e política alcançada no rescaldo de 1962, coadunam -se com a tese de que os trabalhadores agrícolas alentejanos plasmavam uma consciência de classe, ou se se preferir, um habitus atravessado por uma pujante auto-identificação de classe e por uma representação de antagonismo relativamente ao regime ditatorial $e$ às classes dominantes. Simultaneamente, com as conquistas adquiridas com a mobilização colectiva aflora naqueles trabalhadores a percepção de que as estruturas sociais e económicas patentes nos campos alentejanos não são imutáveis mas passíveis de mudança nas suas lógicas de funcionamento.

Os trabalhadores sentiam no fundo de si mesmos que não poderiam ter acesso a um melhor salário sem a mudança de regime. A malta tinha uma grande consciência do que era aquele regime. Sentiam o regime na pele, sabes? Aqui no Alentejo sobretudo, os trabalhadores sempre tiveram uma tendência para lutar muito, logo a malta irritava -se facilmente com as recusas do patrão em dar um melhor salário ou em dar mais emprego. E sempre que a malta protestava lá vinha a GNR desancar no pessoal. Muita gente apanhava sovas da Guarda a fugir dos cavalos. Na prisão ainda era pior. Eu próprio fui torturado. Mas quando temos convicção no ideal que defendemos por muito que nos torturem não sacam nada (HJ).

A noção de dádiva e de dedicação ao que consideravam e proclamavam ser os seus interesses e propósitos de luta era recheada internamente por um sentimento de orgulho na sua condição de contestatários ao regime. A resistência às torturas do cárcere assoma aqui como uma certa mais -valia simbólica na construção do indivíduo e da sua honra perante a comunidade. Vislumbra-se um certo estoicismo na concepção de vida e de moral para a vida, bem como uma serenidade nos próprios gestos e na voz difíceis de imaginar em indivíduos submetidos a torturas e a privações. Ao mesmo tempo, tais vivências contribuem para a construção de um self heroicizado e com uma forte noção de dádiva ${ }^{8}$ e de entrega ao outro colectivo, tornando o resistente operário (e o operário resistente ${ }^{9}$ ) num sinal de equivalência simbólica com uma espécie de figura valorosa e heróica. Em consonância, se ocorre uma coincidência entre essa representação colectiva e o habitus do operariado agrícola alentejano, por conseguinte, despoleta -se um visível sentimento de alegria nos rostos dos indivíduos entrevistados. Uma alegria visível mas, apesar de tudo, intermitente, na medida em que não se manifesta a não ser em determinados momentos explícitos, mormente o seu (quase permanente) estado latente.

As oito horas foram uma satisfação, uma alegria muito grande. Repara. Os trabalhadores saíam de casa ainda de noite e nem viam os filhos e quando chegavam a casa já os fi lhos estavam deitados a dormir. Dali para a frente saíam com sol e chegavam a casa com sol. Isto foi uma coisa espantosa, né? (sorriso rasgado) (GA).

Por seu turno, HJ relata a sua experiência de luta como parte integrante da sua biografia, dos sentimentos que transportou, da ligação entre factos históricos como o desenlace da Segunda Guerra Mundial, os amigos de diferentes classes sociais que se reuniam na luta contra o regime de Salazar. Vidas recortadas por eixos múltiplos de convivialidade e de dimensões políticas, sentimentais e subjectivas em mútua interpenetração.

A minha primeira luta foi em 1945 depois da Segunda Guerra pela democracia. Naturalmente vocês jovens hoje em dia não conseguem compreender o que era o medo do nazi -fascismo e o que significou a derrota daqueles regimes. Foi uma 
alegria só superada pelo 25 de Abril. E era ver a cara de alguns PIDE's que andavam pela região com cara de enterro por causa da derrota do Eixo. Naquele período a politização à esquerda era enorme. Junto dos operários da região quase ninguém se lembrava dos americanos ou dos ingleses. O prestígio da União Soviética e as suas vitórias em Estalinegrado e Kursk estavam na boca do pessoal e de operários mais politizados. E então, neste contexto de euforia que era alimentado pela possibilidade de derrube do fascismo no nosso país, haviam mais de 2500 membros do MUD juvenil em todo o país. Era muita gente, ainda por cima num curto espaço de tempo. Em Beja chegamos a realizar reuniões com mais de 100 jovens operários, intelectuais, pequena -burguesia. Malta democrata, progressista que se dava muito bem connosco comunistas. Respeitavam -nos muito e nós a eles claro. $\mathrm{Na}$ altura havia pequenos -burgueses e intelectuais democratas, intactamente anti fascistas. Hoje nem por isso. Essa malta lia e discutia em conjunto os papéis do MUD. Não tinham medo em colaborar connosco. Muitos não eram pelo socialismo mas eram dignos e não tinham medo de enfrentar o regime $(\mathrm{HJ})$.

45 A história da luta pela democracia também passou pelos campos e pelas aldeias alentejanos. Por "pequenos" e "grandes" momentos. Como eventos históricos de magnitude assinalável - a instauração do regime democrático no dia 25 de Abril de 1974 se afiguram como dificilmente concretizáveis, e no longo curso imperceptíveis, sem a argamassa de toda uma série de actos aparentemente inertes de efeitos, sem linhas nos livros de História, sem espessura para além da fina camada de acções colectivas tornadas memória pelos seus protagonistas anónimos, revelados aqui por via do método biográfico. E que muito para além da nomeação desta ou daquela formação política - que chega a raiar a apoteose -, consistiu na capacidade de a classe trabalhadora se organizar autonomamente e inscrever dinâmicas próprias no revolver da paisagem social.

\section{Conclusão}

46 A História não é a única abordagem possível em Ciências Sociais para estudar o passado de modo sistemático. A metodologia etnográfica - aqui implementada num domínio de recorte mais marcadamente sociológico - pode fornecer relevantes coordenadas, nomeadamente em casos de (tentativa de) reconstituição de determinados objectos de estudo.

Neste artigo procurou demonstrar -se, paralelamente, a existência de uma conexão entre a cultura popular local (valores de solidariedade, produtos culturais de apropriação predominantemente colectiva, redes de sociabilidade, de vizinhança e de interconhecimento), uma cultura de resistência e correspondente materialização prática desse universo simbólico. No fundo, pretendeu-se dar visibilidade a um processo imbricado e recíproco entre um habitus operacionalizado pelo universo sociabilitário e pelos quadros de interacção então vigentes e um habitus operacionável na mobilização colectiva. Atente-se, nesse sentido, no papel da identidade individual e colectiva entronizada no habitus como plataforma giratória entre a comunidade cultural então existente e as práticas sociais e as acções políticas ali accionadas.

Ressalve-se ainda que a abordagem ao objecto de estudo aqui analisado parece consolidar outras pistas de investigação. Entre várias das possíveis podemos enumerar: a formação das classes populares como sujeitos colectivos sociais e políticos; a produção de uma cultura popular característica; o papel dos universos simbólicos e culturais (desde representações sociais mais genéricas até às vivências quotidianas aparentemente mais insignificantes) na construção de uma subjectividade reivindicativa muito própria no 
contexto português; o lugar da metodologia etnográfica e seus métodos e técnicas no decifrar dos códigos de orientação simbólica e significacional dos agentes sociais.

Para terminar, considerou -se neste trabalho a importância de resgatar vozes de agentes de um contexto social praticamente desaparecido. Num futuro breve, raríssimos serão os exemplares vivos desse passado crucial do século XX português. Por conseguinte, afigurou-se como pertinente recolher testemunhos de alguns desses agentes sociais. Nesse sentido, a recuperação (possível e necessariamente parcial) desses relatos de intervenientes directos em eventos históricos (mais ou menos mediáticos, mais ou menos anónimos) convocou essa necessidade sociológica de interpretação da memória histórica conforme ela se expressa nos discursos de protagonistas.

\section{BIBLIOGRAFIA}

ALMEIDA, João Ferreira (1999), Classes sociais nos campos. Oeiras, Celta.

ALVESSON, Mats, e Kaj Skoldberg (2001), Reflexive methodology: new vistas for qualitative research. Londres: Sage.

BAPTISTA, Fernando Oliveira (1993), A Política Agrária do Estado Novo. Porto: Edições Afrontamento.

BARROS, Afonso (1986), Do Latifundismo à Reforma Agrária. O caso de uma Freguesia do Baixo Alentejo. Oeiras: Instituto Gulbenkian de Ciência.

BARROS, Henrique (1980), “O latifúndio - tentativa de caracterização económica”, em Barros, Afonso de (org.), A Agricultura Latifundiária na Península Ibérica. Oeiras: Instituto Gulbenkian de Ciência, pp. 15 -28.

BERTAUX, Daniel (1995), “A Response to Thierry Kochuyt's Biographic and Empiricist Illusions: a reply to recent criticism”, em Biography and Society (annual newsletter of Research Committee 38, Internacional Sociological Association), pp. 2-6.

BOURDIEU, Pierre (2002), Esboço de uma teoria da prática - precedido de três ensaios de etnologia cabila. Oeiras: Celta.

BOURDIEU, Pierre (1998), Razões Práticas, sobre a teoria da acção. Oeiras: Celta.

BURAWOY, Michael (1991), Etnography unbounded, power and resistance in the modern metropolis. Berkeley: University of California Press.

BURAWOY, Michael (1979), Manufacturing consent. Chicago: University of Chicago Press

CALDAS, Eugénio de Castro (1978), A Agricultura portuguesa no Limiar da Reforma Agrária. Oeiras: Instituto Gulbenkian de Ciência.

CHARLESWORTH, Simon J. (2000), A phenomenology of working class experience. Cambridge: Cambridge University Press 
COSTA, António Firmino (2001), “A pesquisa de terreno em Sociologia”. em Pinto, José Madureira, e Silva, Augusto Santos (org.), Metodologia das Ciências Sociais, 11. e. ed. Porto: Edições

Afrontamento, pp. $129-148$.

COSTA, António Firmino (1999), Sociedade de bairro: dinâmicas sociais da identidade. Oeiras: Celta Editora.

CUNHAL, Álvaro (1974), Rumo à Vitória. Porto: A Opinião.

CUTILEIRO, José (1977), Ricos e Pobres no Alentejo. Lisboa: Sá da Costa.

DUBAR, Claude e DEMAZIÉRE, Didier (2004), Analyser les entretiens biographiques. Quebeque: Universidade de Laval.

ESTANQUE, Elísio (2001), Entre a fábrica e a comunidade: subjectividades e práticas de classe no operariado do calçado. Porto: Edições Afrontamento.

FERRAROTI, Francisco (1993), "Sobre la autónomia del método biográfi co", em Marinas J.T., e C. Santamarina (eds.), La Historia Oral: métodos y experiencias. Madrid: Debate, pp. 76 -91.

GODINHO, Paula (2001), Memórias da Resistência Rural no Sul Couço (1958 -1962). Oeiras: Celta

HALL, Stuart (1996), “Who needs identity?”, em Hall, Stuart (eds.), Questions of cultural identity. Londres: Sage, pp. 1 -17.

INE (2008), “Superfície agrícola utilizada (ha) por Localização geográfica (NUTS - 2002) e Classes de superfície agrícola utilizada”, em Ine, Inquérito às Estruturas das Explorações Agrícolas. Lisboa, Instituto Nacional de Estatística.

INE (1981), Censos 1981. Lisboa: Instituto Nacional de Estatística.

JAMES, David (2004), “Contos narrados nas fronteiras: a história de Doña Maria, história oral e questões de género”. em Batalha, Cláudio (org.), Culturas de classe. Campinas: Editora da Unicamp, pp. $287-314$.

KOO, Hagen (2001), Korean workers: the culture and politics of class formation. Ithaca e Londres: Cornell University Press.

LISI, Marco (2007), “O PCP e o processo de mobilização entre 1974 e 1976”. Análise Social, vol. XLII (182), pp.181 -205

LOPES, João Teixeira (2000), A cidade e a cultura: práticas culturais urbanas. Porto: Edições Afrontamento.

LUKACS, Georg (2003), História e consciência de classe. São Paulo: Martins Fontes.

MAUSS, Marcel (2001), Ensaio sobre a dádiva. Lisboa: Edições 70.

MILLER, Daniel (1987), Material culture and mass consumption. Oxford: Basil Blackwell.

MINISTÉRIO DA AGRICULTURA (2001), Evolução das propriedades agrícolas em Portugal (1945-1990). Lisboa: Ministério da Agricultura.

PAIS, José Machado (2001), Ganchos, tachos e biscates. Porto: Âmbar.

PAIS, José Machado (2000), “Introdução”, em J. M. Pais (org.), Traços e riscos de vida. Porto: Âmbar, pp. $5-15$

PEREIRA, Mário (1979), Estrutura Agrária Portuguesa (1968 -1970) - Suas Relações com a População e a Produção Agrícola. Oeiras: Instituto Gulbenkian de Ciência. 
PEREIRA, Virgílio Borges (2005), Classes e culturas de classe das familias portuguesas: classes sociais e modalidades de estilização da vida na cidade do Porto. Porto: Edições Afrontamento.

RIESSMAN, Catherine Kohler (2003), “Analysis of personal narratives”, em Holstein, James, e Jaber Gubrium (org.), Inside interviewing - new lenses, new concerns. Thousand Oaks: Sage, pp. 331 -346 .

SILVA, Manuel Carlos (1998), Resistir a adaptar -se: constrangimentos e estratégias camponesas no noroeste de Portugal, Porto: Edições Afrontamento.

THOMPSON, Edward (1991), The formation of the English working class. Londres: Penguin

WACQUANT, Loic (2004), Body and soul: notebooks of an apprentice boxer. Nova Iorque e Oxford: Oxford University Press.

WRIGHT, Erik Olin (1997), Class counts. Cambridge: Cambridge University Press

\section{NOTAS}

1. A questão de um objecto de estudo em vias de perder a sua existência real coaduna-se com o grau mais ou menos variável de determinados segmentos das classes populares em conseguirem reproduzir-se, social e culturalmente. Para citar apenas alguns dos mais recentes, os estudos de Elísio Estanque ou de Virgílio Borges Pereira, respectivamente, debruçam -se sobre as difi culdades de reprodução do operariado do calçado em São João da Madeira e do operariado industrial tradicional que habitava largas parcelas do Centro Histórico da cidade do Porto (Estanque 2001; Pereira 2005). Nenhum dos casos mencionados atinge, pelo menos por ora, o grau de desestruturação do operariado agrícola alentejano que tem vindo a desagregar-se à medida que a renovação geracional se desvincula cada vez mais da produção agrícola, mais ainda, dos moldes intensivos de aplicação de trabalho humano à produção agrícola. O vigoroso estudo de Manuel Carlos Silva (1998) sobre comunidades camponesas minhotas também aborda alguns dos problemas com que o campesinato se debate para assegurar a própria reprodução (das condições de produção) da classe.

2. Apesar dessa escassez atente -se em relevantes estudos que procuraram caracterizar o panorama socioeconómico alentejano ao longo do século XX (Cutileiro 1977; Caldas 1978; Pereira 1979; Barros 1980; Baptista 1980; Barros 1986; Baptista 1993; Godinho, 2001). Repare-se que grande parte destes estudos foram realizados em finais da década de 70 ou inícios dos anos 80 e, genericamente, a vertente do estudo dos universos simbólicos e culturais é secundária.

3. Como defende Stuart Hall, «as identidades são construídas dentro, e não fora, dos discursos» (Hall 1996: 4).

4. Neste respeitante, não deixou de nos causar uma certa surpresa a quase obrigatoriedade com que os entrevistados nos impuseram a segunda pessoa do singular no entabular das entrevistas. Portanto, o tratamento por "tu" entre ambas as partes denuncia uma expressividade própria daqueles agentes e da forma como ela mesma colocou ao investigador a necessidade de adequar um instrumento que inerentemente implica distanciamento - a entrevista como ferramenta técnica de apreensão de informação sociologicamente pertinente - com uma comunicação interpessoal que teve de assentar numa relação de familiaridade discursiva, sob pena de se perder a recolha de informação empírica.

5. De referir que das mais de trinta entrevistas realizadas aquando do nosso processo de pesquisa obtiveram-se três histórias de vida com as quais trabalhamos neste artigo. Por outro lado, o processo de investigação etnográfica empreendido utilizou outras técnicas como a fotografia social, a observação directa, a análise de conteúdo de poesia popular e análise documental. Por 
economia de espaço e por motivos de delimitação temática centramo-nos nas técnicas da entrevista e da construção de histórias de vida.

6. Importa ressaltar que, per si, a substância do discurso político do entrevistado não assume qualquer tipo de relevância teórica para o nosso trabalho. A pertinência sociológica relaciona-se mais com a presente capacidade dos agentes na organização e coerência de raciocínios.

7. A conceptualização bourdiana do conceito de habitus é por demais reconhecida: «um habitus, entendido como um sistema de disposições duradouras e transponíveis que, integrando todas as experiências passadas, funciona a cada momento como uma matriz de percepções, de apreciações e de acções» (Bourdieu 2002: 167) [itálicos do autor]. Não iremos debater detalhadamente as virtualidades ou as limitações do conceito, mas registar o que, a nosso ver, constitui o carácter mais inovador desta categoria teórica. Por um lado, a relação que estabelece entre estrutura e acção e entre os níveis macro e micro. Por outro lado, e mais relevante para o painel de elaboração analítica aqui em causa, o habitus surge como uma plataforma agregadora das diversas matérias -primas simbólicas, culturais e sociais que são interiorizadas pelos agentes sociais e que se objectivam (Miller 1987: 33), por sua vez, no constante e variável rearranjo do espaço social. Assumindo esta característica do habitus como fundamental para o nosso objecto de estudo e menos uma certa rigidez na determinação dos fenómenos sociais imputada ao conceito ou, se se considerar mais simples, a uma certa unidireccionalidade das estruturas sobre as práticas. Daí que ocorra uma certa fluidez no recurso a termos como habitus, consciência de classe ou quadros de interacção, na medida em que precisamente se procura captar a dimensão da referida plataforma de confluência de disposições sociais e simbólico-culturais.

8. A noção de dádiva aqui veiculada é, em alguns aspectos, naturalmente distinta da estudada por Mauss no seu estudo clássico sobre os mecanismos do potlach na Polinésia. Contudo, existem alguns elementos relativamente próximos, nomeadamente quando o antropólogo francês concebe a dádiva da seguinte forma: «dois elementos essenciais são nitidamente atestados: o da honra, o do prestígio, e o da obrigação absoluta de retribuir essas dádivas sob pena de perder esse "mana", essa autoridade, esse talismã, essa fonte de riqueza que é a própria autoridade» (Mauss 2001: 60). O peso da honra como ferramenta de prestígio social nos elementos mais envolvidos na luta contra o regime - no sentido da ligação entre os operários resistentes e os resistentes operários (vd. nota 8 ) - que não vive sem a atribuição de autoridade das populações àqueles. 0 sentimento de autoridade, visto em termos de liderança política e simbólica naquelas comunidades alentejanas, implica um sentimento de cumprimento da honra esperada (a abnegação e a capacidade de resistência) e da coragem evidenciada em momentos de tensão (sublinhe-se o comportamento nos cadafalsos da ditadura ou a preparação e desencadear de iniciativas de contestação nas ruas das localidades alentejanas), só para citar dois exemplos paradigmáticos.

9. O operário resistente enuncia o assalariado agrícola que apoia e participa em iniciativas de protesto. Por seu turno, o resistente operário refere-se ao indivíduo que era maioritariamente originário do operariado agrícola alentejano e, com o passar do tempo, se tornava, por via da selecção e promoção de quadros do e pelo Partido Comunista, num operacional profissionalizado e clandestino que actua na organização e coordenação de movimentações sociais e políticas. 0 efeito da socialização do lugar de origem de classe (Almeida 1999: 76 -84) constitui -se como um indicador explicativo possível para se poder compreender a maior facilidade que o PCP teve na sua ligação ao operariado agrícola da região. 


\section{RESUMOS}

Os contextos sociais e históricos já desaparecidos foram desde sempre um desafio para as Ciências Sociais. Neste trabalho tentaremos abordar alguns eixos da subjectividade do operariado agrícola alentejano durante a ditadura do Estado Novo (1928-1974). Ao mesmo tempo, a ênfase no método biográfico surge aqui como um caminho possível de parcialmente reconstruir um cenário de estudo praticamente extinto.

Vanished social and historical contexts have always been a challenge for Social Sciences. This paper is an attempt to answer some questions regarding the subjectivity of rural workers in the province of Alentejo during the period of dictatorship, also known as Estado Novo (1928-1974). At the same time, the emphasis on a biographical method seems to be here a possible path for a partial reconstruction of an almost vanished scenario.

Les contextes sociaux et historiques déjà disparus sont toujours un défi pour les sciences sociales. Dans ce texte, nous essaierons d'appréhender certaines dimensions de la subjectivité des ouvriers agricoles de l'Alentejo pendant la dictature portugaise de l'État nouveau (1928-1974). En même temps, nous mettons l'accent sur la méthode biographique comme un moyen de reconstruire partiellement un scenario d'étude pratiquement disparu.

\section{ÍNDICE}

Palavras-chave: método biográfico, etnografia, operariado agrícola, cultura

Keywords: biographical method, ethnography, rural working class, popular culture

Mots-clés: méthode biographique, ethnographie, ouvriers agricoles, culture populaire

\section{AUTOR}

\section{JOÃO VALENTE AGUIAR}

Investigador Integrado do Instituto de Sociologia da Universidade do Porto, joaovalenteaguiar@gmail.com 